\title{
Childhood Membranous Nephropathy, Circulating Antibodies to the 58-kD TIN Antigen, and Anti-Tubular Basement Membrane Nephritis: An 11-Year Follow-Up
}

\author{
Béla Iványi, MD, PhD, Ibolya Haszon, MD, Emöke Endreffy, MD, PhD, Päl Szenohradszky, MD,
} Ildikó B. Petri, MD, PhD, Tibor Kalmár, MD, Ralph J. Butkowski, MD, PhD, Aristidis S. Charonis, MD, PhD, and Sándor Túri, MD, PhD

\begin{abstract}
- Childhood membranous nephropathy (MNP) with anti-tubular basement membrane (anti-TBM) nephritis is a rare disorder that may have extrarenal manifestations. This article describes a new case to be added to the 10 previously reported. A renal biopsy specimen from a 1-year-old white boy with nephrotic syndrome, microhematuria, and hypertension showed MNP (granular global IgG, IgA and C3, and segmental IgM and C1q) associated with hypercellularity and granular deposits of $\operatorname{lgM}$ and $C 1 q$ in the mesangium, arteriolar $\lg A$, and $\operatorname{linear} T B M \lg G$, $\lg A$, and C3. A biopsy at age 4 years showed MNP (IgG and C3) and linear IgG and C3 along the TBM. Six months later, temporary glucosuria suggested a mild tubular dysfunction. Biopsy at age 8 years showed sclerosing MNP (IgG and C3), linear TBM IgG and C3, and chronic active tubulointerstitial nephritis (TIN). Indirect immunofluorescence showed circulating anti-TBM antibodies, and the enzyme-linked immunosorbent assay (ELISA) approach verified strong reactivity with the 58-kd TIN antigen. Despite trials with steroids, chlorambucil, azathioprine, and cyclosporine, end-stage renal disease developed by the age of 9 years. At age 10 years, the patient received a cadaveric kidney transplant. With the patient now aged 12 years, the graft is still functioning well, without any clinical evidence of disease recurrence. Neurological, ocular, and abdominal symptoms, including nonbacterial diarrhea, were observed during the follow-up period. The pathophysiology of these extrarenal symptoms remains unclear. Serotyping and genotyping of HLA antigens (A2, A10, B12, B41, DR5 [1101, 1103-4, 1106 or 1108-1113], DR6 [1303, 1312 , or 1413], DRB3 [*0101 and 0201-2 or 0301], DQA1 [*0501 homozygous], and DQB1 [ ${ }^{\star} 0301$ homozygous]) did not indicate any HLA association similar to those decribed previously in childhood MNP with anti-TBM nephritis (HLA-B7 in four patients, HLA-DR8 in two patients). The presented case is the fifth in the literature that displays reactivity with the 58-kd TIN antigen, and for which data on HLA antigens are reported.

(1) 1998 by the National Kidney Foundation, Inc.
\end{abstract}

INDEX WORDS: Membranous nephropathy; anti-tubular basement membrane nephritis; tubulointerstitial nephritis antigen; HLA class I and II antigens; renal transplantation; tubular dysfunction; end-stage renal disease.

$\mathbf{M}$ EMBRANOUS nephropathy (MNP) is infrequent in children, with an incidence below 5\%.1,2 Childhood MNP occasionally may be associated with linear ${ }^{3-9}$ or granular ${ }^{10,11}$ depos-

From the Department of Pathology, the Clinics of Pediatrics, the Renal Transplantation Unit, Department of Surgery, and the HLA-Typing and Blood Transfusion Laboratory, Albert Szent-Györgyi Medical University, Szeged, Hungary; the Institute of Genetics, Biological Research Center, Hungarian Academy of Sciences, Szeged, Hungary; the INCSTAR Corporation, Stillwater, MN; and the Department of Laboratory Medicine and Pathology, University of Minnesota Medical School, Minneapolis, MN, and the Department of Anatomy, University of Patras Medical School, Patras, Greece.

Received January 20, 1998; accepted in revised form June 12, 1998

Supported by grants (to B.I.) OTKA T-016525 and ETT588/1996-06, Budapest, Hungary and (to T.S.) OTKA T-025010, Budapest, Hungary.

Address reprint requests to Béla Iványi, $M D, P h D$, Associate Professor of Pathology, Department of Pathology, Albert Szent-Györgyi Medical University, H-6724 Szeged, Kossuth L. sgt. 40 (H-6701 Szeged, pf. 401), Hungary. E-mail: ivanyi@morpho.szote.u-szeged.hu

(1) 1998 by the National Kidney Foundation, Inc. 0272-6386/98/3206-0022\$3.00/0 its of immunoglobulin $\mathrm{G}(\mathrm{IgG})$ and $\mathrm{C} 3$ along the tubular basement membrane (TBM). The linear immunodeposits indicate the presence of antiTBM nephritis. Primary anti-TBM nephritis is characterized by linear TBM immunodeposits, interstitial mononuclear infiltrates, tubulitis, tubular damage/atrophy, interstitial fibrosis, the ultrastructural absence of electron-dense deposits in the TBM, circulating anti-TBM antibodies, a tubular dysfunction, and progressive azotemia. ${ }^{12-14}$ Anti-TBM antibodies have been occasionally documented at times in a variety of renal diseases, ${ }^{15}$ such as drug-induced tubulointerstitial nephritis (TIN), ${ }^{16}$ anti-glomerular basement membrane nephritis, ${ }^{17}$ renal allografts, ${ }^{18}$ poststreptococcal glomerulonephritis, ${ }^{19}$ lupus nephritis,,$^{20}$ and MNP of children. ${ }^{3-9}$ The latter association is the subject of the current communication.

\section{CASE REPORT}

A 10-month-old white boy was admitted with the nephrotic syndrome (proteinuria: $3.9 \mathrm{~g} /$ day, serum albumin level: $2.1 \mathrm{~g} / \mathrm{dL}$, edema), microhematuria, and hypertension 
(130/80 mm Hg). Serum studies showed normal electrolytes, creatinine, and the third complement component (C3). Glucosuria and aminoaciduria were not detected. In response to a daily prednisone regimen of $60 \mathrm{mg} / \mathrm{m}^{2}$ body surface area (BSA), the proteinuria decreased to $0.2 \mathrm{~g} / 24 \mathrm{~h}$, the hematuria disappeared, and the blood pressure normalized. Within 2 months, however, the patient became steroid dependent, and a percutaneous kidney biopsy was performed (March 1987). Results of tests for lupus erythematosus cell and anti-DNA antibody were negative. The treatment was continued with prednisone $(1 \mathrm{mg} / \mathrm{kg} / \mathrm{d})$ and indomethacine $(1 \mathrm{mg} / \mathrm{kg} / \mathrm{d})$, given alternately. At the age of 3 years, the patient had epileptic seizures, which were treated with carbamazepine. At the age of 4 years, the proteinuria became steroid resistant, and the nephrotic syndrome was manifested again (proteinuria: $6 \mathrm{~g} / \mathrm{d}$ ). Additional findings were microhematuria, a reduced urine concentrating capacity, hypertension (140/90 mm Hg), and normal serum creatinine and glucose levels. Glucosuria and aminoaciduria were still not observed. A new renal biopsy was performed (May 1990). Subsequently, a 6-week period of chlorambucil (0.2 $\mathrm{mg} / \mathrm{kg} / \mathrm{d}$ ) and prednisone (40 $\mathrm{mg} / \mathrm{m}^{2}$ BSA every other day) was initiated, but without success.

Methylprednisolone pulse therapy $(3 \times 500 \mathrm{mg})$ was then tried, followed by a 6-week azathioprine $(1 \mathrm{mg} / \mathrm{kg} / \mathrm{d})$ treatment. The proteinuria fluctuated between 0.5 and $6 \mathrm{~g} / 24 \mathrm{~h}$; the hematuria persisted. The hypertension was treated with an angiotensin-converting enzyme inhibitor, a Ca-channel blocker, and diuretics, and the hypercholesterinemia with bezafibrate. At the age of 4.5 years, glucosuria was observed ( $250 \mathrm{mg} / \mathrm{L}$ to $1.3 \mathrm{~g} / \mathrm{L}$ ), although the blood glucose levels were in the normal range. The glucosuria later disappeared. At the age of 5 years, the child suffered from frequent headaches, bulbar pain, visual disturbances associated with nausea, vomiting, tremor, a broad-based gait, abdominal pain, and nonbacterial diarrhea reminiscent of a lactase deficiency. The results of cranial radiograph, computed tomography scan, and ophthalmological investigations were negative. Electroencephalogram showed only a mild irregular cerebral activity. The explanation of these unusual symptoms remains unclear. The ocular and abdominal complaints slowly ceased. Because the laboratory tests constantly verified the nephrotic syndrome and azotemia appeared (serum creatinine $1.4 \mathrm{mg} / \mathrm{dL}$ ), a low-protein diet and cyclosporine A $(4 \mathrm{mg} / \mathrm{kg} / \mathrm{d})$ were initiated. The administration of cyclosporine was stopped 2 months later because the neurological symptoms had worsened; this was attributed to the side effects of the drug. At the age of 8 years, the serum creatinine was $2 \mathrm{mg} / \mathrm{dL}$, and the creatinine clearance was reduced to $30 \mathrm{~mL} / \mathrm{min} / \mathrm{m}^{2}$. Despite forced antihypertensive therapy, the patient had an elevated blood pressure (150/100 $\mathrm{mm} \mathrm{Hg}$ ). A further renal biopsy was performed (June 1994), and the serum of the patient was tested toward circulating anti-TBM antibodies. At the age of 9 years, chronic hemodialysis was started, and after 13 months of bicarbonate hemodialysis, the patient underwent a successful cadaveric kidney transplantation. The native kidneys were not removed. The child is now 12 years of age, and his allograft is functioning well, without clinical evidence of the recurrence of the disease. He is receiving cyclosporine, azathioprine, and steroid. The most recent parameters include the follow- ing: proteinuria below $0.5 \mathrm{~g} / \mathrm{day}$, no glucosuria, serum creatinine, electrolyte and acid-base levels normal, and blood pressure normal $(100 / 70 \mathrm{~mm} \mathrm{Hg})$.

\section{Morphological Studies}

The renal biopsy specimens were processed for light microscopy, direct immunofluorescence (IF) (IgG, IgA, IgM, fibrinogen, C3 and C1q), and electron microscopy with standard methods. Indirect IF was performed on normal human kidney tissue to detect circulating anti-TBM antibodies.

\section{Immunochemical Analysis}

The serum obtained at the time of the third biopsy (1994) was used to test the reactivity of antibodies toward the 58-kd TIN antigen by enzyme-linked immunosorbent assay (ELISA), and other components of the TBM by Western blotting, as described. ${ }^{5}$

\section{HLA Serotyping and Genotyping}

Serologic HLA class I and class II typing was performed before renal transplantation, with standard methods. The genotyping of HLA-DRB, DQA1, and DQB1 alleles was performed in total cellular DNA isolates from peripheral blood leukocytes. For HLA-DRB analysis, the Amplicor kit (Hoffman-La Roche, Basel, Switzerland) was applied. The DQA1 typing was performed with a modified PCR-RFLP procedure, ${ }^{21}$ and the DQB1 typing with the INNO-LiPA/ DQB1 kit.

\section{RESULTS}

The renal biopsy findings are summarized in Table 1. MNP and linear staining with IgG along the TBMs are shown in Figs 1 and 2, respectively.

Indirect IF showed circulating anti-TBM antibodies at a concentration of 1:16 (Fig 3). Circulating anti-TBM antibodies were tested 1 and 2 years after transplantation, with negative results. The ELISA approach disclosed a high reactivity of the 58-kd TIN antigen at dilutions of 1:250, 1:50, and 1:10. Even at the 250-fold dilution, the reactivity was strong at 1 minute. In the Western blot experiment, no reactivity was detected.

The serotyping of HLA antigens showed A2, A10, B12, B41, DR5, and DR6 antigens. The genotyping verified DR5 (1101, 1103-4, 1106 or 1108-1113), DR6 (1303, 1312, or 1413), DRB3 $(* 0101$ and $0201-2$ or 0301$)$, DQA1 $(* 0501$ homozygous), and DQB1 (*0301 homozygous) alleles.

\section{DISCUSSION}

With the addition of the presented case (patient 11 ) to the previously described ones, 11 
Table 1. Renal Biopsy Findings

\begin{tabular}{|c|c|c|c|c|}
\hline Year & & Light Microscopy & Direct Immunoflurescence & Electron Microscopy \\
\hline \multirow[t]{4}{*}{1987} & Glomerular tufts & $\begin{array}{l}\text { Segmental thickening with } \\
\text { spikes }\end{array}$ & $\begin{array}{l}\text { Granular IgG, IgA and C3; seg- } \\
\text { mental IgM and C3 }\end{array}$ & MNP, stage II-III \\
\hline & Mesangium & $\begin{array}{l}\text { Foc-segm proliferation and } \\
\text { increase of matrix }\end{array}$ & Granular IgM and C1q & Electron-dense deposits \\
\hline & TIS & Normal & $\begin{array}{l}\text { Linear } \lg G, \lg A \text {, and } C 3 \text { along } \\
60 \% \text { of the TBMs }\end{array}$ & No deposits \\
\hline & Vessels & Normal & One arteriole: $\lg A$ & Arterioles: no change \\
\hline \multirow[t]{4}{*}{1990} & Glomerular tufts & Diffusely thickened, spikes & Granular IgG and C3 & Relapsing MNP, stage II-III \\
\hline & Mesangium & No change & No deposits & No deposits \\
\hline & TIS & Normal & $\begin{array}{l}\text { Linear IgG and } \mathrm{C} 3 \text { along } 70 \% \text { of } \\
\text { the TBMs }\end{array}$ & No deposits \\
\hline & Vessels & No change & No change & Not available \\
\hline \multirow[t]{3}{*}{1994} & Glomeruli & $\begin{array}{l}\text { Mainly sclerotic, open tufts: } \\
\text { thickened, spikes }\end{array}$ & $\begin{array}{l}\text { Granular IgG and C3 in patent } \\
\text { glomeruli }\end{array}$ & Sclerotic \\
\hline & TIS & $\begin{array}{l}\text { ISF, TA, focal mononuclear infil- } \\
\text { trates, } 2+\text { tubulitis }\end{array}$ & $\begin{array}{l}\text { Linear IgG and C3 along the } \\
\text { TBM }\end{array}$ & No deposits \\
\hline & Vessels & $\begin{array}{l}\text { Arterioles with } 2-3 \text { smooth } \\
\text { muscle layers }\end{array}$ & No change & Not available \\
\hline
\end{tabular}

NOTE. In 1987 and 1990, the tubular immunostaining was interpreted as pseudolinear. In 1994, the diagnosis of sclerosing MNP associated with chronic active anti-TBM nephritis was set up.

Abbreviations: MNP, membranous nephropathy; Foc-segm, focal and segmental; ISF, interstitial fibrosis; TA, tubular atrophy; 2+, 7 lymphocytes/profile; TBM, tubular basement membrane; TIS, tubulointerstitium.

cases of childhood MNP with anti-TBM nephritis have been published in the English literature (Table 2). The clinical features include a male preponderance, onset in early childhood (median age at renal biopsy, 3 years), nephrotic-range proteinuria, microhematuria, complete or incomplete Fanconi syndrome, circulating antibodies against the TBM, and renal insufficiency. Two patients responded to steroid treatment. Progression to end-stage renal disease was reported in

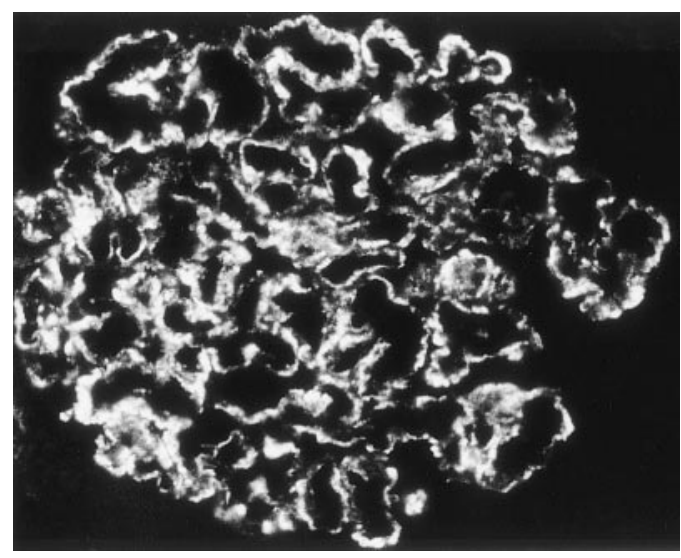

Fig 1. Membranous nephropathy: Granular deposits of IgG along glomerular capillaries (original magnification $\times 160$ ). six patients. Four patients received a renal transplant. The anti-TBM nephritis recurred in patient 5. Graft loss, however, was due to chronic rejection 3.5 years after transplantation. ${ }^{5}$

During the past few years, several autoantigens have been isolated from collagenase digests of the human TBM. ${ }^{22-24}$ Among these, the 58-kd TIN antigen is a glycoprotein macromolecule ${ }^{25,26}$ that promotes epithelial cell adhesion. ${ }^{27,28}$ Immunofluorescence found that the TIN antigen had the highest expression in the $\mathrm{BM}$ of the proximal tubules. The expression was lower in the BM of the Bowman's capsules and distal tubules and

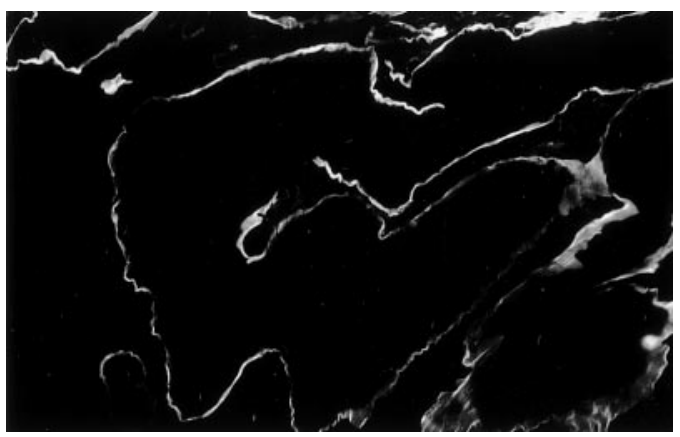

Fig 2. Linear immunostaining of IgG along tubular basement membranes (original magnification $\times 160$ ). 


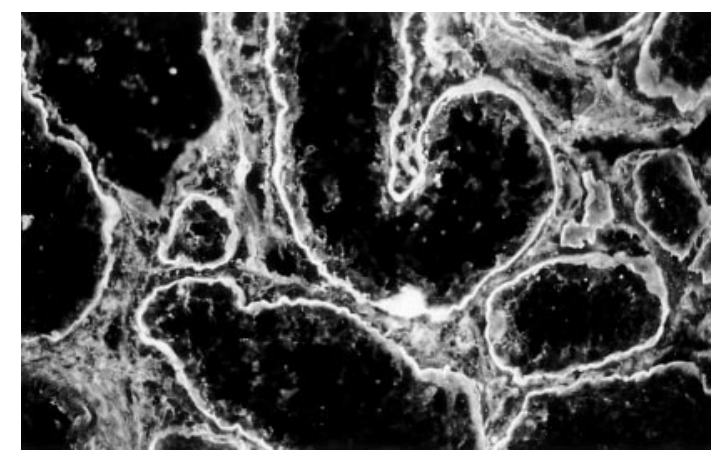

Fig 3. Normal human renal cortex incubated with the patient's serum $(1: 16)$ and stained with rabbit antihuman IgG: Linear tubular basement membrane deposition of $\lg G$ can be seen (original magnification $\times 160$ ).

was absent from the glomerular $\mathrm{BM}$ and the mesangial matrix. In extrarenal tissues, the TIN antigen was localized in the small intestinal, corneal, and epidermal BMs. ${ }^{29}$ In our patient, the ELISA approach showed that the patient's antibodies strongly recognize the 58-kd TIN antigen. The results from the immunoblotting approach were negative, and therefore nothing could be said as to whether the serum reacted with other TBM components besides the TIN antigen. The negativity may be because the autoantibodies are unable to recognize the 58-kd molecule in the conformation present after electrophoresis and blotting. In patients 3, 4, and 5, Western blotting showed a light stain for a $175-\mathrm{kd}$ TBM protein, which could be the 58-kd form bound to another protein, or a trimer of the $58-\mathrm{kd}$ form. ${ }^{5}$ Because the anti-TBM antibodies strongly reacted with the 58-kd TIN antigen in all five patients tested so far (Table 2), the 58-kd form seems to be the primary target antigen in anti-TBM nephritis.

The first biopsy showed the coexistence of MNP, hypercellularity and granular immunodeposits of the mesangium, and linear immunostaining along the TBM. Mesangial-immunocomplex nephritis-like changes have not been observed in cases of childhood MNP with anti-TBM nephritis. The second biopsy, however, did not show the mesangial alterations seen in the first biopsy, either because of the intrinsic nature of the disease, or as a consequence of the therapy. The clinical picture in our patient was predominated by the nephrotic syndrome and hypertension. Although TBM immunodeposits were already present at the times of the first and second biopsies, the clinical and morphological signs of
anti-TBM nephritis were not manifested in the first 3 years of the disease. Later, temporary glucosuria was observed, indicating a mild tubular dysfunction, and the third biopsy, 7 years after the onset, showed chronic active TIN. Similarly to what was found in our patient, in patients 2,6 , and 8 , the immunodeposits along the TBM were not associated with detectable defects in the tubular function at the time of the biopsy, and in patients 6 and 8, the TBM immunodeposits were not accompanied by light microscopic evidence of TIN. The first biopsy in patients 7 and 10 verified the MNP but did not show any light microscopic or immunomorphological change in the tubulointerstitium, and the renal symptoms at the time of the biopsy did not indicate tubulointerstitial disease. These data strongly suggest that in childhood MNP with anti-TBM nephritis, the glomerular disease is the primary lesion, and the formation of anti-TBM antibodies, their fixation to the TBM, and the development of TIN and tubular dysfunction are secondary phenomena. The manner in which MNP elicits the formation of anti-TBM antibodies is unclear. It may be interesting to mention that also in primary MNP associated with formation of anti-glomerular BM antibody, MNP — as characterized by long-standing nephrotic syndrome and granular immune deposits on the epithelial side of the glomerular $\mathrm{BM}$ - seems to precede the anti-glomerular BM response and the development of rapidly progressive, crescentic glomerulonephritis. ${ }^{30,31}$ In our patient, the end-stage kidneys were not removed at transplantation. Because the MNP or antiTBM nephritis did not recur after transplantation, the autoimmune process seemed to be "burned out" during the months of chronic hemodialysis.

Childhood MNP may exhibit extrarenal organ involvement, such as the intestinal villous atrophy in patient 8 , or the lung hemorrhage in patients 1 and 9 . In patient 8 , high titers of circulating autoantibodies directed against the cytoplasm of the intestinal epithelial cells were verified. Direct IF, however, did not show immunoglobulin or complement deposition in the intestinal epithelium, which makes the role of the anti-intestinal epithelial cell antibody in producing intestinal injury uncertain. ${ }^{7}$ The pathomechanism of the lung hemorrhage in patient 9 was unresolved. The nature of the extrarenal symp- 
Table 2. Features of Childhood Membranous Nephropathy With Anti-TBM Nephritis

\begin{tabular}{|c|c|c|c|c|c|c|c|c|}
\hline Patient & $\begin{array}{l}\text { Biopsy } \\
\text { (age in } \\
\text { years) }\end{array}$ & $\begin{array}{c}\text { Renal } \\
\text { Symptoms }\end{array}$ & TIN & $\begin{array}{l}\text { TBM } \\
\text { lgG }\end{array}$ & $\begin{array}{c}\text { Circulating } \\
\text { Anti-TBM ABs }\end{array}$ & $\begin{array}{c}\text { Renal } \\
\text { Outcome }\end{array}$ & $\begin{array}{l}\text { Extrarenal } \\
\text { Involvement }\end{array}$ & Reference \\
\hline 1, Boy & 3.8 & $\begin{array}{l}\text { Proteinuria, Fan- } \\
\text { coni syn- } \\
\text { drome, azo- } \\
\text { temia }\end{array}$ & Yes & $\begin{array}{r}\text { Linear and } \\
\text { granular }\end{array}$ & Positive & ESRD at 5 y & $\begin{array}{l}\text { Lung infiltrates, } \\
\text { anti-alveolar } \\
\text { BM Abs }\end{array}$ & 3 \\
\hline 2, Boy & 7 & $\begin{array}{l}\text { NS; incomplete } \\
\text { Fanconi syn- } \\
\text { drome } 1 \text { year } \\
\text { later }\end{array}$ & Yes & Linear & Positive & Not reported & $\begin{array}{l}\text { Earlier: gluten- } \\
\text { sensitive } \\
\text { celiakia }\end{array}$ & 4 \\
\hline 3, Boy & 3.7 & $\begin{array}{l}\text { NS, microhema- } \\
\text { turia, glucos- } \\
\text { uria }\end{array}$ & Yes & Linear & Positive* & $\begin{array}{l}\text { ESRD at } 13 \mathrm{y} ; \\
\mathrm{Tx}\end{array}$ & Not reported & 5 \\
\hline \multirow[t]{2}{*}{ 4, Boy } & 2.2 & $\begin{array}{l}\text { NS, microhema- } \\
\text { turia, glucos- } \\
\text { uria }\end{array}$ & Yes & Linear & Positive* & & Not reported & 5 \\
\hline & 2.5 & NS, azotemia & Yes & Linear & Positive & ESRD; Tx & & \\
\hline 5, Boy & 4.5 & $\begin{array}{l}\text { NS, microhema- } \\
\text { turia, Fanconi } \\
\text { syndrome }\end{array}$ & Prob & Not reported & Positive after $T x^{*}$ & $\begin{array}{l}\text { ESRD at } 11.5 \mathrm{y} ; \\
\text { Txt }\end{array}$ & Not reported & 5 \\
\hline \multirow[t]{2}{*}{ 6, Boy } & 1.7 & $\begin{array}{l}\text { NS, microhema- } \\
\text { turia; no } \\
\text { tubular } \\
\text { defects }\end{array}$ & No & Linear & Negative & & Not reported & 6 \\
\hline & 6 & $\begin{array}{l}\text { Proteinuria, Fan- } \\
\text { coni syn- } \\
\text { drome, azo- } \\
\text { temia }\end{array}$ & Yes & Linear & Negative & $\begin{array}{l}\text { Renal insuffi- } \\
\text { ciency }\end{array}$ & & \\
\hline \multirow[t]{2}{*}{ 7, Girl } & 10 & $\begin{array}{l}\text { NS, microhema- } \\
\text { turia; glucos- } \\
\text { uria later }\end{array}$ & No & No deposit & Negative & & Not reported & 6 \\
\hline & 14 & $\begin{array}{l}\text { Proteinuria, } \\
\text { tubular } \\
\text { defects, azo- } \\
\text { temia }\end{array}$ & Yes & Linear & Negative & $\begin{array}{l}\text { Renal insuffi- } \\
\text { ciency }\end{array}$ & & \\
\hline 8, Boy & 3 & $\begin{array}{l}\text { NS, microhema- } \\
\text { turia, no } \\
\text { tubular } \\
\text { defects }\end{array}$ & No & Linear & Positive & $\begin{array}{l}\text { Responded to } \\
\text { steroid }\end{array}$ & $\begin{array}{l}\text { Malabsorption, } \\
\text { villous atrophy }\end{array}$ & 7 \\
\hline \multirow[t]{2}{*}{ 9, Boy } & 2.2 & $\begin{array}{l}\text { Proteinuria, azo- } \\
\text { temia; no } \\
\text { tubular } \\
\text { defects }\end{array}$ & No & No deposit & Not tested & & $\begin{array}{l}\text { Anemia, dys- } \\
\text { pnea }\end{array}$ & 8 \\
\hline & 3 & $\begin{array}{l}\text { NS, Fanconi } \\
\text { syndrome, } \\
\text { azotemia }\end{array}$ & Yes & Linear & Positive & ESRD at $8 y$ & $\begin{array}{l}\text { Alveolar hemor- } \\
\text { rhage, no anti- } \\
\text { alveolar BM } \\
\text { Abs }\end{array}$ & \\
\hline \multirow[t]{2}{*}{ 10, Boy } & 0.9 & $\begin{array}{l}\text { NS, microhema- } \\
\text { turia; no } \\
\text { tubular } \\
\text { defects }\end{array}$ & No & No deposit & Not tested & & & 9 \\
\hline & 2 & $\begin{array}{l}\text { NS, microhema- } \\
\text { turia, Fanconi } \\
\text { syndrome }\end{array}$ & Yes & Linear & Positive* & $\begin{array}{l}\text { Responded to } \\
\text { steroid }\end{array}$ & Not reported & \\
\hline \multirow[t]{3}{*}{ 11, Boy } & 1 & $\begin{array}{l}\text { NS, microhema- } \\
\text { turia, no } \\
\text { tubular } \\
\text { defects }\end{array}$ & No & Linear & Not tested & & $\begin{array}{l}\text { At } 3 \text { y: epilepsy, } \\
\text { at } 5 \text { y: ocular, } \\
\text { neurological, } \\
\text { and }\end{array}$ & $\begin{array}{l}\text { Presented } \\
\text { case }\end{array}$ \\
\hline & 4 & $\begin{array}{l}\text { NS, microhema- } \\
\text { turia; glucos- } \\
\text { uria later }\end{array}$ & No & Linear & Not tested & & $\begin{array}{l}\text { abdominal } \\
\text { symptoms }\end{array}$ & \\
\hline & 8 & NS, azotemia & Yes & Linear & Positive* & ESRD at $9 \mathrm{y} ; \mathrm{Tx}$ & & \\
\hline
\end{tabular}

Abbreviations: TBM, tubular basement membrane; Ab, antibody; NS, nephrotic-range proteinuria; TIN, tubulointerstitial nephritis by light microscopy; ESRD, end-stage renal disease; Tx, kidney transplantation; prob, probable.

${ }^{*}$ Reactivity with the 58-kd TIN antigen.

†The anti-TBM nephritis recurred in the graft. 
toms in our patient also remained unexplored. Conceivably, the abdominal and ocular complaints could stem from a mild, temporary immune injury to the small bowel and cornea, as the basement membranes of these tissues also contain the TIN antigen. The neurological symptoms might be associated in part with the immune injury to the choroid plexus and the disturbed production of cerebrospinal fluid. ${ }^{32}$ Because our patient has been on cyclosporine since renal transplantation, and the drug has not affected his neurological status adversely, the worsening of the neurological symptoms at age 7 was unlikely to have been attributable to a side effect of cyclosporine, as thought originally.

The HLA status has so far been examined in patients 3, 4, 5, and 10. All carried the B7 antigen, and patients 3 and 4 were also positive for the DR8 antigen, suggesting that childhood MNP with anti-TBM nephritis may be HLAlinked, and the B7 or DR8 antigens provide disease susceptibility. In healthy Hungarian individuals, the DQA1 *0501 and DQB1 *0301 alleles predominate, ${ }^{33}$ and these alleles in our patient therefore belong to the normal profile. In patients with MNP from England, Germany, and France, the DR3 antigen has been found to be frequent, often in association with the A1 and B8 antigens. ${ }^{34-37}$ In Hungarian patients with MNP, only the $\mathrm{A} 1$ and $\mathrm{A} 3$ antigens, but not the $\mathrm{B} 8$, DR2, or DR3 antigens, have been shown to have an increased incidence. ${ }^{38}$ In conclusion, the HLA status of our patient differed from any association with HLA-antigens previously reported in childhood MNP with anti-TBM nephritis or primary MNP in whites.

\section{REFERENCES}

1. Habib R, Kleinknecht C, Gubler MC: Extramembranous glomerulonephritis in children. J Pediatr 82:754-766, 1973

2. Report of the International Study of Kidney Disease in Children: Nephrotic syndrome in children: prediction of histopathology from clinical and laboratory characteristics at time of diagnosis. Kidney Int 13:159-165, 1978

3. Levy M, Gagnadoux MF, Beziau A, Habib R: Membranous glomerulonephritis associated with anti-tubular and anti-alveolar basement membrane antibodies. Clin Nephrol 10:158-165, 1978

4. Levy M, Guesry P, Loirat C, Dommergues JP, Nivet H, Habib R: Immunologically mediated tubulointerstitial nephritis in children. Contrib Nephrol 16:132-140, 1979

5. Katz A, Fish AJ, Santamaria P, Nevins TE, Kim Y, Butkowski RJ: Role of antibodies to tubulointerstitial nephri- tis antigen in human anti-tubular basement membrane nephritis associated with membranous nephropathy. Am J Med 93:691-698, 1992

6. Wood EG, Brouhard BH, Travis LB, Cavallo T, Lynch RE: Membranous glomerulonephropathy with tubular dysfunction and linear tubular basement membrane IgG deposition. J Pediatr 101:414-417, 1982

7. Martini A, Scotta MS, Notarangelo D, Maggiore G, Guarnaccia S, de Giacomo G: Membranous glomerulopathy and chronic small-intestinal enteropathy associated with autoantibodies directed against renal tubular basement membrane and the cytoplasm of intestinal epithelial cells. Acta Paediatr Scand 72:931-934, 1983

8. Gallego N, Olivares F, Mampaso F, Gonzalo A, Barrio R, Estepa R, Ortuno J: Membranous nephropathy, antitubular basement membrane antibodies and alveolar hemorrhage in a diabetic child. Child Nephrol Urol 10:154-157, 1990

9. Makker SP, Widstrom R, Huang J: Membranous nephropathy, interstitial nephritis, and Fanconi syndrome: Glomerular antigen. Pediatr Nephrol 10:7-13, 1996

10. Tung KSK, Black WC: Association of renal glomerular and tubular immune complex disease and antitubular basement membrane antibody. Lab Invest 32:696-700, 1975

11. Ellis D, Fisher SE, Smith WI, Jaffe R: Familial occurrence of renal and intestinal disease associated with tissue autoantibodies. Am J Dis Child 136:323-326, 1982

12. Bergstein J, Litman N: Interstitial nephritis with antitubular-basement-membrane antibody. N Engl J Med 292: $875-878,1975$

13. Brentjens JR, Noble B, Andres GA: Immunologically mediated lesions of kidney tubules and interstitium in laboratory animals and in man. Springer Semin Immunopathol 5:357-378, 1982

14. Brentjens JR, Matsuo S, Fukatsu A, Min I, Kohli R, Anthone R, Anthone S, Biesecker G, Andres G: Immunologic studies in two patients with antibular basement membrane nephritis. Am J Med 86:603-608, 1989

15. Colvin RB, Fang LST: Interstitial nephritis, in Tisher CC, Brenner BM (eds): Renal Pathology With Clinical and Functional Correlations. Philadelphia, PA, Lippincott, 1994, pp 723-768

16. Baldwin DS, Levine BB, McCluskey RT, Gallo GR: Renal failure and interstitial nephritis due to penicillin and methicillin. N Engl J Med 279:1245-1252, 1968

17. Andres G, Brentjens J, Kohli R, Anthone R, Anthone S, Baliah T, Montes M, Mookerjee BK, Prezyna A, Sepulveda M, Venuto R, Elwood C: Histology of human tubulointerstitial nephritis associated with antibodies to renal basement membranes. Kidney Int 13:480-491, 1978

18. Orfila C, Durand D, Vega-Vidallé C, Suc JM: Immunofluorescent deposits on the tubular basement membrane in human renal transplant. Nephron 57:149-155, 1991

19. Morel-Maroger L, Kourilsky O, Mignon F, Richet G: Antitubular basement membrane antibodies in rapidly progressive poststreptococcal glomerulonephritis: Report of a case. Clin Immunol Immunopathol 2:185-194, 1974

20. Makker SP: Tubular basement membrane antibodyinduced interstitial nephritis in systemic lupus erythematosus. Am J Med 69:949-952, 1980

21. Ota M, Seki T, Nomura N, Sugimura K, Mizuki N, Fukushima H, Tsuji K, Inoko H: Modified PCR-RFLP 
method for HLA-DPB1 and DQA1 genotyping. Tissue Antigens 38:60-71, 1991

22. Clayman MD, Michaud L, Brentjens J, Andres GA, Kefalides NA, Neilson EG: Isolation of the target antigen of human anti-tubular basement membrane antibody-associated interstitial nephritis. J Clin Invest 77:1143-1147, 1986

23. Yoshioka K, Morimoto Y, Iseki T, Maki S: Characterization of tubular basement membrane antigens in human kidney. J Immunol 136:1654-1660, 1986

24. Fliger FD, Wieslander J, Brentjens JR, Andres GA, Butkowski RJ: Identification of a target antigen in human anti-tubular basement membrane nephritis. Kidney Int 31: 800-807, 1987

25. Crary GS, Katz A, Fish AJ, Michael AF, Butkowski RJ: Role of a basement membrane glycoprotein in antitubular basement membrane nephritis. Kidney Int 43:140146,1993

26. Nelson TR, Charonis AS, McIvor RS, Butkowksi RJ: Identification of a cDNA encoding tubulointerstitial nephritis antigen. J Biol Chem 270:16265-16270, 1995

27. Kalfa TA, Thull JD, Butkowski RJ, Charonis AS: Tubulointerstitial nephritis antigen interacts with laminin and type IV collagen and promotes cell adhesion. J Biol Chem 269:1654-1659, 1994

28. Chen Y, Krishnamurti U, Wayner EA, Michael AF, Charonis AS: Receptors in proximal epithelial cells for tubulointerstitial nephritis antigen. Kidney Int 49:153-157, 1996

29. Butkowski RJ, Kleppel MM, Katz A, Michael AF, Fish AJ: Distribution of tubulointerstitial nephritis antigen and evidence for multiple forms. Kidney Int 40:838-846, 1991

30. Klassen J, Elwood C, Grossberg A, Milgrom F, Montes M, Sepulveda M, Andres GA: Evolution of membranous nephropathy into anti-glomerular-basement-membrane glomerulonephritis. N Engl J Med 290:1340-1344, 1974

31. Thitiarchakul S, Lal SM, Luger A, Ross G: Goodpas- ture's syndrome superimposed on membranous nephropathy: A case report. Int J Artif Organs 18:763-765, 1995

32. Macintosh RM, Copack P, Chernak WB, Griswals WR, Weil R III, Koss MN: The human choroid plexus and autoimmune nephritis. Arch Pathol 99:48-50, 1975

33. Varga É, Endreffy E, Samu G, Szekeres É, Tóth F, Bede O, Petri I: Molecular genetic analysis of HLA-DRB, -DQA, and -DQB polymorphism in Hungarians and distribution of the DRB1*03 allele in adults and newborns. Exp Clin Immunogenet 13:204-209, 1996

34. Klouda PT, Manos J, Acheson EJ, Dyer PA, Goldby FS, Harris R, Lawler W, Mallick NP: Strong association between idiopathic membranous nephropathy and HLADRw3. Lancet 2:770-771, 1979

35. Müller GA, Müller C, Liebau G, Kömpf J, Ising H, Wernet P: Strong association of idiopathic membranous nephropathy (IMN) with HLA-DR 3 and MT-2 without involvement of HLA-B 18 and no association to BfF1. Tissue Antigens 17:332-337, 1981

36. Berthoux FC, Laurent B, le Petit JC, Genin C, Broutin F, Touraine F, Hassan AA, Champailler A: Immunogenetics and immunopathology of human primary membranous glomerulonephritis: HLA-A, B, DR antigens: Functional activity of splenic macrophage Fc-receptors and peripheral blood T-lymphocyte subpopulations. Clin Nephrol 22:15-20, 1984

37. Papiha SS, Pareek SK, Rodger RSC, Morley AR, Wilkinson R, Roberts DF, Kerr DNS: HLA-A, B, DR and Bf allotypes in patients with idiopathic membranous nephropathy (IMN). Kidney Int 31:130-134, 1987

38. Mohácsi G, Petri I, Gál G, Sonkodi S: Possible prognostic values of the antibody-dependent cellular cytotoxicity (ADCC)-test and HLA-typing in patients with idiopathic membranous glomerulonephritis (IMGN). 22nd Congress of the International Society of Internal Medicine, Budapest, Hungary, 28 August to 2 September 1994, Bologna, Italy, Monduzzi, 1994, pp 185-188 